\title{
EFFECT OF A PROTEIN-XANTHOPHYLL CONCENTRATE FROM ALFALFA AND OF GENOTYPE AND SEX OF LAMBS ON THEIR BLOOD REDOX PROFILE*
}

\author{
KATARZYNA OGNIK, KRZYSZTOF PATKOWSKI ${ }^{1}$, AND EUGENIUSZ R. GRELA ${ }^{2}$ \\ Department of Biochemistry and Toxicology, \\ ${ }^{1}$ Department of Small Ruminants Breeding and Agricultural Consultancy, \\ ${ }^{2}$ Institute of Animal Nutrition and Bromatology, Faculty of Biology and Breeding, \\ University of Life Sciences in Lublin, 20-950 Lublin \\ kasiaognik@poczta.fm
}

Received: November 28, 2011

Accepted: May 15, 2012

\begin{abstract}
The experiment was conducted on lambs of the Polish Lowland sheep (PLS) and a synthetic BCP line. The redox potential was assessed in blood of lambs with different genotype and sex, which were fed feed mixtures with various contents of a proteinxanthophyll (PX) concentrate from alfalfa (1.5\% and 3\%). The $1.5 \%$ addition of PX concentrate to feed stimulated the response of the antioxidant defence mechanisms of the lambs to a greater extent than the $3 \%$ addition. The study showed that sex of the lambs had no significant effect on changes in the redox parameters of blood. The PLS genotype of lambs determined higher values of superoxide dismutase (SOD), total antioxidant potential of plasma (FRAP), malondialdehyde, and vitamin C than the BCP genotype. Along with the growth of the lambs, a descending tendency was observed in SOD and catalase levels, and an ascending tendency in FRAP value.
\end{abstract}

Key words: lambs, alfalfa, protein-xanthophyll, redox parameters.

The feeding of lambs exerts a significant effect on their rearing performance. It may also contribute to the modification of their metabolism and, consequently, to the improvement of their health status. A proteinxanthophyll (PX) concentrate from lucerne (alfalfa), containing ca. $550 \mathrm{~g}$ of total protein and over 1,200 mg of xanthophylls per $1 \mathrm{~kg}$ of the preparation, additionally possesses a number of other valuable active compounds, e.g., saponin glycosides (2\%-3\%), polyphenolic compounds, compounds exhibiting oestrogenic activity (biochanin $\mathrm{A}$, daidzein), as well as vitamins ( $\mathrm{A}, \mathrm{B}_{1}, \mathrm{~B}_{6}$, $\left.\mathrm{B}_{12}, \mathrm{C}, \mathrm{E}, \mathrm{K}\right)$, provitamins ( $\beta$-carotene), and mineral compounds $(22,10)$. The presence of numerous groups of active substances determines the multi-directional pharmacological effects displayed by alfalfa and products made of it (16). Many of these active compounds - polyphenols, vitamins $\mathrm{E}$ and $\mathrm{C}$, and $\beta$ carotene in particular, apart from immunomodulating properties $(9,14,19)$ exhibit antioxidative properties (1). Nevertheless, it is worth emphasising that, besides feeding, changes in the metabolism of animals (including the antioxidative status) may also be affected by a variety of other factors, including: genotype, sex, and age of animal, and by a study period.

The objective of this research was to evaluate the blood redox potential of lambs with different genotype and sex, fattened feed mixtures with various contents of a protein-xanthophyll (PX) concentrate from alfalfa.

\section{Material and Methods}

The study was conducted in Experimental Station in Bezek of the University of Life Science in Lublin in two replications in the years 2009 and 2010. Ninety six lambs of two genotypes: the Polish Lowland Sheep (PLS) and synthetic BCP line divided into forty eight animals (24 males and 24 females) within each group were used in the experiment. The animals of each genotype and sex were stratified as analogues into three nutritional groups. Respective groups consisted of thirty two lambs. Group - C the control group was fed the standard full- dose mixture, whereas both experimental group E-1 and E-2 received the same standard mixture but enriched with $1.5 \%$ or $3 \%$ of protein- xanthophyll (PX) concentrate from alfalfa, respectively, given instead of soybean meal. PX concentrate (DesialisFrance Luzerne) was dosed in the full-dose mixture balanced for the respective rearing periods (Table 1) since day 10 of life till weaning (90-100 d of life) (16). In addition, lambs of all groups were receiving a structural additive of meadow hay during the entire period of rearing with mothers. The feeding of lamb mothers was consistent with demands provisioned in the lactation period (17). A feed dose was composed of hay silage (3-4 kg), full-dose feed mixtures (oat grain and wheat bran in the ratio of $3: 1$, in the quantity of $0.5-0.7$ $\mathrm{kg} / \mathrm{animal})$, hay $(0.8 \mathrm{~kg} / \mathrm{animal})$, and straw ad libitum. The animals were kept in a sheep shed under identical 
conditions, on deep litter, and with free access to drinking water.

In order to analyse redox parameters, blood was sampled from lambs in the $4^{\text {th }}, 8^{\text {th }}$, and $12^{\text {th }}$ week of their life. In blood plasma, superoxide dismutase (SOD) was assayed spectrophotometrically by the adrenaline method, according to Misra (15), at the $320 \mathrm{~nm}$ wavelength. The method was modified in order to achieve greater selectivity of transitory reaction products at this wavelength (4). Additionally, catalase (CAT) level was analysed according to Bartosz (4). In the case of the antioxidative system parameters, the ferric reducing ability of plasma (FRAP) was analysed according to Benzie and Strain (5), and vitamin $C$ was determined according to Omaye et al. (24). Samples of blood plasma were also analysed for levels of lipid peroxidation products: peroxides $\left(\mathrm{H}_{2} \mathrm{O}_{2}\right)-$ according to Gay and Gębicki (12, 13), and malondialdehyde (MDA) - the end product of tissue lipid oxidation - according to Salih et al. (25).

The obtained results were analysed statistically using the analysis of variance with the least squares method (SAS 2003) and the following model:

$$
Y_{i j k l m n}=\mu \vdash \boldsymbol{J}_{i}+{ }_{j}+\supset_{k}+?_{l}+i_{i j k l m}
$$

where:

$$
\begin{array}{ll}
Y_{i j k l m n} & \text { - value of parameter } \\
\mu & \text { - mean of all assays } \\
G_{i} & \text { - effect of genotype (BCP, PLS) } \\
P_{j} & \text { - effect of sex (ram, ewe) } \\
D_{k} & \text { - effect of group (C, E-1, E-2) } \\
R_{l} & \text { - effect of the year of the study (2009, } \\
2010) & \\
e_{i j k l m n} & \text { - random error }
\end{array}
$$

\section{Results}

Effect of PX concentrate. The values of prooxidative and anti-oxidative parameters achieved in blood plasma of the lambs are presented in Table 1-3. The addition of PX concentrate to feed mixtures caused a significant decrease in the activity of superoxide dismutase in group E-1 ( $4^{\text {th }}$ week of life $)$ and in group E$2\left(12^{\text {th }}\right.$ week of life $)$ in comparison to the control group. In the $8^{\text {th }}$ and $12^{\text {th }}$ week of life, in lambs fed the feed mixture with $1.5 \%$ content of the PX concentrate the suppressed activity of catalase was also noted, when compared to the control group. The administration of $1.5 \%$-PX caused a significant increase in FRAP, compared to the control animals, which was correlated with a reduced concentration of vitamin $\mathrm{E}$ in the $8^{\text {th }}$ week of life. It is worth noting, however, that the longer administration period of the feed mixture with $1.5 \% \mathrm{PX}$ content triggered a significant increase in vitamin $\mathrm{C}$ level, recorded in the $12^{\text {th }}$ week of lambs' life. In contrast, the addition of $3 \%$-PX contributed to a significant decrease in FRAP level only in the first period of administration ( $4^{\text {th }}$ week). Furthermore, the addition of $3 \%$ PX concentrate resulted in a decreased level of vitamin C (a constituent of FRAP) in the $8^{\text {th }}$ week of lambs' life. The application of both doses $(1.5 \%$ and $3 \%$ ) of the PX concentrate to the feed mixtures did not increase the levels of lipid peroxidation products $\left(\mathrm{H}_{2} \mathrm{O}_{2}\right.$ and MDA) neither in the $4^{\text {th }}$ nor in the $8^{\text {th }}$ week of lambs' life. Nevertheless, in group E-1, a higher level of MDA was observed in the $12^{\text {th }}$ week of lambs' life, compared to the control group.

Effect of sex, genotype, and the study year. The analysis of the obtained results demonstrated that sex of the lambs had no impact on the values of most of the analysed parameters, except for MDA, whose higher $(\mathrm{P} \leq 0.01)$ value was noted in the $4^{\text {th }}$ week of ewes' life. In contrast, animal genotype exerted a significant effect on the activity of SOD $(\mathrm{P} \leq 0.05)$ and FRAP $(\mathrm{P} \leq 0.01)$, as well as on the levels of MDA $(\mathrm{P} \leq 0.05)$ and vitamin $\mathrm{C}$ $(P \leq 0.01)$. Significantly higher values of these blood parameters were determined in the PLS lambs.

The year of the study was also found to affect the investigated blood parameters. In the experiment conducted in 2010 , over the entire fattening period, the level of MDA was significantly higher than the respective value recorded in 2009. In addition, the experiment carried out in 2010 reduced the levels of lipid peroxides $\left(4^{\text {th }}\right.$ and $8^{\text {th }}$ week of life) and vitamin $C$ ( $4^{\text {th }}$ and $12^{\text {th }}$ week of life) as well as increased the activity of SOD ( $4^{\text {th }}$ week of life $)$ and CAT $\left(8^{\text {th }}\right.$ week of life).

The observed changes in the redox parameters of lambs' blood, occurring during the growth period of the animals, constitute very interesting results. A descending tendency was noted for the activity of SOD and CAT in the older lambs. In contrast, the FRAP was observed to increase along with the growth of the lambs. Furthermore, when analysing changes in the values of pro-oxidative parameters $\left(\mathrm{H}_{2} \mathrm{O}_{2}\right.$ and MDA), their initial increase was observed up to the $8^{\text {th }}$ week of life, which was followed by a decrease noted in the $12^{\text {th }}$ week of lambs' life. In contrast, the age of the lambs did not affect vitamin $\mathrm{C}$ level in their blood plasma.

Table 1

Composition of a feed mixture for lambs (\%)

\begin{tabular}{lcccccc}
\hline \multirow{2}{*}{ Component } & \multicolumn{3}{c}{$\begin{array}{c}\text { I period of } \\
\text { fattening }\end{array}$} & \multicolumn{3}{c}{$\begin{array}{c}\text { I period of } \\
\text { fattening }\end{array}$} \\
\cline { 2 - 8 } & \multicolumn{2}{c}{$10-30 \mathrm{~d}$ of life } & \multicolumn{3}{c}{ Over 30 d of life } \\
\cline { 2 - 8 } & $\mathrm{C}$ & $\mathrm{E}-1$ & $\mathrm{E}-2$ & $\mathrm{C}$ & $\mathrm{E}-1$ & $\mathrm{E}-2$ \\
\hline Oat & 39 & 39 & 39 & 35 & 35 & 35 \\
\hline Wheat & 15 & 15 & 15 & 15 & 15 & 15 \\
\hline Barley & 15 & 15 & 15 & 15 & 15 & 15 \\
\hline Wheat bran & 15 & 15 & 15 & 15 & 15 & 15 \\
\hline Dry beet pulp & 8 & 8 & 8 & 8 & 8 & 8 \\
\hline $\begin{array}{l}\text { Extracted soybean } \\
\text { meal }\end{array}$ & 7 & 5.5 & 4 & 11 & 9.5 & 8 \\
\hline $\begin{array}{l}\text { PX concentrate } \\
\text { from alfalfa }\end{array}$ & - & 1.5 & 3 & - & 1.5 & 3 \\
\hline $\begin{array}{l}\text { Mineral-vitamin } \\
\text { premix - Dolfos for } \\
\text { lambs }\end{array}$ & 1 & 1 & 1 & 1 & 1 & 1 \\
\hline
\end{tabular}


Table 2

Pro-oxidative and antioxidative parameters in blood in the $4{ }^{\text {th }}$ week of lambs' life

\begin{tabular}{|c|c|c|c|c|c|c|c|c|c|c|c|}
\hline \multirow[b]{2}{*}{ Parameter } & & \multicolumn{2}{|c|}{ Genotype (G) } & \multicolumn{2}{|c|}{$\operatorname{Sex}(S)$} & \multicolumn{3}{|c|}{ Experimental group (E) } & \multicolumn{2}{|c|}{ Study year (Y) } & \multirow[b]{2}{*}{$\begin{array}{l}\text { Effect of } \\
\text { interaction }\end{array}$} \\
\hline & & $\begin{array}{l}\text { BCP } \\
\mathrm{n}=48\end{array}$ & $\begin{array}{l}\text { PLS } \\
\mathrm{n}=48\end{array}$ & $\begin{array}{l}\text { Ewes } \\
\mathrm{n}=48\end{array}$ & $\begin{array}{l}\text { Rams } \\
\mathrm{n}=48\end{array}$ & $\begin{array}{c}\text { Control } \\
\text { (C) } \\
n=32\end{array}$ & $\begin{array}{c}1.5 \% \\
\text { PX (E- } \\
1) \\
n=32 \\
\end{array}$ & $\begin{array}{c}3 \% \\
\mathrm{PX} \\
(\mathrm{E}-2) \\
\mathrm{n}=32 \\
\end{array}$ & $\begin{array}{l}2009 \\
\mathrm{n}=48\end{array}$ & $\begin{array}{l}2010 \\
\mathrm{n}=48\end{array}$ & \\
\hline \multirow{2}{*}{$\begin{array}{l}\text { SOD } \\
\mathrm{U} \mathrm{mL}^{-1}\end{array}$} & LSM & 99.15 & 94.66 & 97.70 & 96.11 & $112.63^{\mathrm{a}}$ & $85.29^{\mathrm{b}}$ & $\begin{array}{c}92.79 \\
\mathrm{ab}\end{array}$ & $64.49 * *$ & $112.31 * *$ & \multirow{2}{*}{ GxD** } \\
\hline & SE & 9.39 & 7.39 & 8.96 & 7.88 & 11.68 & 7.58 & 10.99 & 1.37 & 9.41 & \\
\hline \multirow{2}{*}{$\begin{array}{l}\text { CAT } \\
\mathrm{U} \mathrm{mL}^{-1}\end{array}$} & LSM & 5.52 & 5.44 & 5.48 & 5.48 & 5.86 & 5.44 & 5.15 & 5.80 & 5.16 & \multirow{2}{*}{ ns } \\
\hline & $\mathrm{SE}$ & 0.38 & 0.31 & 0.34 & 0.36 & 0.46 & 0.41 & 0.41 & 0.31 & 0.37 & \\
\hline \multirow{2}{*}{$\begin{array}{l}\text { FRAP } \\
\mu \mathrm{mol} \mathrm{L}{ }^{-1}\end{array}$} & LSM & $58.47 * *$ & $75.84 * *$ & 69.92 & 64.39 & $77.02^{\mathrm{A}}$ & $75.85^{\mathrm{A}}$ & $58.59^{\mathrm{B}}$ & $58.71 * *$ & $75.59 * *$ & \multirow{2}{*}{ GxR** } \\
\hline & SE & 3.18 & 4.40 & 4.49 & 3.46 & 2.55 & 5.75 & 4.07 & 3.36 & 4.20 & \\
\hline \multirow{2}{*}{$\begin{array}{l}\text { VIT.C } \\
\text { mg L L }^{-1}\end{array}$} & LSM & 0.25 & 0.28 & 0.26 & 0.27 & $0.27^{\mathrm{ab}}$ & $0.29^{\mathrm{a}}$ & $0.24^{\mathrm{b}}$ & $0.28^{*}$ & $0.25^{*}$ & \multirow{2}{*}{$\mathrm{GxR}^{* *}$} \\
\hline & SE & 0.01 & 0.01 & 0.01 & 0.01 & 0.01 & 0.02 & 0.01 & 0.01 & 0.01 & \\
\hline \multirow{2}{*}{$\begin{array}{l}\mathrm{H}_{2} \mathrm{O}_{2} \\
\mu \mathrm{mol} \mathrm{L}{ }^{-1}\end{array}$} & LSM & 4.09 & 3.54 & 3.90 & 3.71 & 3.48 & 4.84 & 3.11 & $4.54 * *$ & $3.07 * *$ & \multirow{2}{*}{ ns } \\
\hline & SE & 0.29 & 0.28 & 0.31 & 0.27 & 0.31 & 0.37 & 0.29 & 0.23 & 0.30 & \\
\hline \multirow{2}{*}{$\begin{array}{l}\text { MDA } \\
\mu \mathrm{mol} \mathrm{L}^{-1}\end{array}$} & LSM & $0.66^{*}$ & $0.75 *$ & $0.76 * *$ & $0.65 * *$ & 0.79 & 0.60 & 0.73 & $0.27 * *$ & $1.14 * *$ & \multirow{2}{*}{ ns } \\
\hline & SE & 0.06 & 0.08 & 0.08 & 0.06 & 0.09 & 0.07 & 0.11 & 0.01 & 0.05 & \\
\hline
\end{tabular}

$\mathrm{a}, \mathrm{b}$ - means within the row with no common superscript differ significantly at $\mathrm{P} \leq 0.05$ (comparison to control group I) A, B - means within the row with no common superscript differ significantly at $\mathrm{P} \leq 0.01$ (comparison to control group I) ns: not significant $(\mathrm{P}>0.05) ; *(\mathrm{P} \leq 0.05) ; * *(\mathrm{P} \leq 0.01)$

$\mathrm{SOD}$ - superoxide dismutase, CAT - catalase, FRAP - total antioxidant potential of plasma, VIT C - vitamin $\mathrm{C}, \mathrm{H}_{2} \mathrm{O}_{2}-$ peroxides, MDA - malondialdehyde

Table 3

Pro-oxidative and antioxidative parameters in blood in the $8^{\text {th }}$ week of lambs' life

\begin{tabular}{|c|c|c|c|c|c|c|c|c|c|c|c|}
\hline \multirow[b]{2}{*}{ Parameter } & & \multicolumn{2}{|c|}{ Genotype (G) } & \multicolumn{2}{|c|}{$\operatorname{Sex}(\mathrm{S})$} & \multicolumn{3}{|c|}{ Experimental group (E) } & \multicolumn{2}{|c|}{ Study year (Y) } & \multirow[b]{2}{*}{$\begin{array}{l}\text { Effect of } \\
\text { interaction }\end{array}$} \\
\hline & & $\begin{array}{l}\text { BCP } \\
\mathrm{n}=48\end{array}$ & $\begin{array}{l}\text { PLS } \\
\mathrm{n}=48\end{array}$ & $\begin{array}{l}\text { Ewes } \\
\mathrm{n}=48\end{array}$ & $\begin{array}{l}\text { Rams } \\
\mathrm{n}=48\end{array}$ & $\begin{array}{c}\text { Control } \\
\text { (C) } \\
n=32\end{array}$ & $\begin{array}{c}1.5 \% \mathrm{PX} \\
(\mathrm{E}-1) \\
\mathrm{n}=32\end{array}$ & $\begin{array}{c}3 \% \mathrm{PX} \\
(\mathrm{E}-2) \\
\mathrm{n}=32\end{array}$ & $\begin{array}{l}2009 \\
\mathrm{n}=48\end{array}$ & $\begin{array}{l}2010 \\
\mathrm{n}=48\end{array}$ & \\
\hline \multirow{2}{*}{$\begin{array}{l}\text { SOD } \\
\mathrm{U} \mathrm{mL}^{-1}\end{array}$} & LSM & 80.47 & 72.01 & 76.34 & 76.14 & 86.86 & 74.42 & 67.45 & 71.31 & 81.18 & \multirow{2}{*}{ ns } \\
\hline & $\mathrm{SE}$ & 10.43 & 2.01 & 5.16 & 9.77 & 14.98 & 4.45 & 5.65 & 1.21 & 10.75 & \\
\hline \multirow{2}{*}{$\begin{array}{l}\text { CAT } \\
\mathrm{U} \mathrm{mL}^{-1}\end{array}$} & LSM & 3.90 & 3.47 & 3.52 & 3.86 & $4.58^{\mathrm{a}}$ & $3.03^{\mathrm{b}}$ & $3.46^{\mathrm{ab}}$ & $2.35 * *$ & $5.03 * *$ & \multirow{2}{*}{ ns } \\
\hline & $\mathrm{SE}$ & 0.41 & 0.45 & 0.39 & 0.47 & 0.59 & 0.43 & 0.52 & 0.15 & 0.51 & \\
\hline \multirow{2}{*}{$\begin{array}{c}\text { FRAP } \\
\mu \mathrm{mol} \mathrm{L}^{-1}\end{array}$} & LSM & $\begin{array}{c}50.88 * \\
*\end{array}$ & $\begin{array}{c}66.89 * \\
*\end{array}$ & 59.40 & 58.36 & $48.36^{\mathrm{B}}$ & $74.24^{\mathrm{A}}$ & $\underset{\mathrm{B}}{54.04^{\mathrm{A}}}$ & $\begin{array}{c}71.13^{*} \\
*\end{array}$ & $\begin{array}{c}46.63 * \\
*\end{array}$ & \multirow{2}{*}{$\begin{array}{l}\text { GxR** } \\
\text { DxR** }\end{array}$} \\
\hline & $\mathrm{SE}$ & 4.09 & 2.66 & 3.63 & 3.68 & 2.93 & 5.43 & 3.20 & 3.16 & 3.18 & \\
\hline \multirow{2}{*}{$\begin{array}{l}\text { VIT.C } \\
\mathrm{mg} \mathrm{L}^{-1}\end{array}$} & LSM & $0.23 * *$ & $0.30 * *$ & 0.27 & 0.26 & $0.34^{\mathrm{A}}$ & $0.23^{\mathrm{B}}$ & $0.22^{\mathrm{B}}$ & $0.28 *$ & $0.25^{*}$ & \multirow{2}{*}{$\mathrm{DxR}^{* *}$} \\
\hline & $\mathrm{SE}$ & 0.01 & 0.02 & 0.01 & 0.01 & 0.02 & 0.01 & 0.01 & 0.01 & 0.02 & \\
\hline \multirow{2}{*}{$\begin{array}{c}\mathrm{H}_{2} \mathrm{O}_{2} \\
\mu \mathrm{mol} \mathrm{L}^{-1}\end{array}$} & LSM & $4.65^{*}$ & $4.13^{*}$ & 4.37 & 4.42 & $4.21^{\mathrm{AB}}$ & $5.15^{\mathrm{A}}$ & $3.81^{\mathrm{B}}$ & $4.77 *$ & $4.02 *$ & \multirow{2}{*}{$\mathrm{GxR}^{* *}$} \\
\hline & $\mathrm{SE}$ & 0.21 & 0.23 & 0.19 & 0.25 & 0.29 & 0.26 & 0.20 & 0.19 & 0.24 & \\
\hline \multirow{2}{*}{$\begin{array}{c}\text { MDA } \\
\mu \mathrm{mol} \mathrm{L}^{-1}\end{array}$} & LSM & 0.80 & 0.82 & 0.81 & 0.82 & 0.83 & 0.84 & 0.78 & $0.25 * *$ & $1.37 * *$ & \multirow{2}{*}{ ns } \\
\hline & SE & 0.08 & 0.09 & 0.08 & 0.09 & 0.10 & 0.11 & 0.10 & 0.02 & 0.03 & \\
\hline
\end{tabular}

Symbols as in the footnote to Table 2 . 
Table 4

Pro-oxidative and antioxidative parameters in blood in the $12^{\text {th }}$ week of lambs' life

\begin{tabular}{|c|c|c|c|c|c|c|c|c|c|c|c|}
\hline \multirow[b]{2}{*}{ Parameter } & & \multicolumn{2}{|c|}{ Genotype (G) } & \multicolumn{2}{|c|}{ Sex $(S)$} & \multicolumn{3}{|c|}{ Experimental group (E) } & \multicolumn{2}{|c|}{ Study year (Y) } & \multirow[b]{2}{*}{$\begin{array}{l}\text { Effect of } \\
\text { interaction }\end{array}$} \\
\hline & & $\begin{array}{l}\text { BCP } \\
\mathrm{n}=48\end{array}$ & $\begin{array}{c}\text { PLS } \\
\mathrm{n}=48\end{array}$ & $\begin{array}{l}\text { Ewes } \\
n=48\end{array}$ & $\begin{array}{c}\text { Rams } \\
\mathrm{n}=48\end{array}$ & $\begin{array}{c}\text { Control } \\
\text { (C) } \\
n=32\end{array}$ & $\begin{array}{c}1.5 \% \\
\text { PX } \\
(\mathrm{E}-1) \\
\mathrm{n}=32 \\
\end{array}$ & $\begin{array}{c}3 \% \mathrm{PX} \\
(\mathrm{E}-2) \\
\mathrm{n}=32\end{array}$ & $\begin{array}{l}2009 \\
\mathrm{n}=48\end{array}$ & $\begin{array}{l}2010 \\
n=48\end{array}$ & \\
\hline \multirow{2}{*}{$\begin{array}{l}\text { SOD } \\
\mathrm{U} \mathrm{mL}^{-1}\end{array}$} & LSM & $20.83^{*}$ & $22.95^{*}$ & 21.64 & 22.14 & $34.20^{\mathrm{A}}$ & $17.54^{\mathrm{B}}$ & $13.94^{\mathrm{B}}$ & 21.76 & 22.02 & \multirow{2}{*}{ ns } \\
\hline & SE & 1.34 & 1.51 & 1.49 & 1.44 & 1.00 & 0.60 & 0.48 & 1.47 & 1.46 & \\
\hline \multirow{2}{*}{$\begin{array}{l}\text { CAT } \\
\mathrm{U} \mathrm{mL}^{-1}\end{array}$} & LSM & 2.55 & 2.38 & 2.39 & 2.55 & $2.59^{\mathrm{AB}}$ & $1.60^{\mathrm{B}}$ & $3.21^{\mathrm{A}}$ & 2.43 & 2.51 & \multirow{2}{*}{$\mathrm{GxP} *$} \\
\hline & SE & 0.18 & 0.14 & 0.15 & 0.16 & 0.16 & 0.10 & 0.18 & 0.16 & 0.16 & \\
\hline \multirow{2}{*}{$\begin{array}{l}\text { FRAP } \\
\mu \mathrm{mol} \mathrm{L}^{-1}\end{array}$} & LSM & 123.82 & 132.08 & 131.91 & 123.98 & $129.49^{\mathrm{ab}}$ & $120.71^{\mathrm{b}}$ & $133.64^{\mathrm{a}}$ & 128.55 & 127.34 & \multirow{2}{*}{ ns } \\
\hline & SE & 2.76 & 3.26 & 3.94 & 2.15 & 3.23 & 4.16 & 3.75 & 3.35 & 2.93 & \\
\hline \multirow{2}{*}{$\begin{array}{l}\text { VIT.C } \\
\text { mg L }^{-1}\end{array}$} & LSM & 0.21 & 0.20 & 0.20 & 0.20 & $0.17^{\mathrm{B}}$ & $0.25^{\mathrm{A}}$ & $0.18^{\mathrm{AB}}$ & $0.28 * *$ & $0.13 * *$ & \multirow{2}{*}{$\mathrm{GxR}^{* *}$} \\
\hline & SE & 0.02 & 0.02 & 0.01 & 0.02 & 0.01 & 0.03 & 0.02 & 0.02 & 0.00 & \\
\hline \multirow{2}{*}{$\begin{array}{l}\mathrm{H}_{2} \mathrm{O}_{2} \\
\mu \mathrm{mol} \mathrm{L}{ }^{-1}\end{array}$} & LSM & 2.86 & 2.75 & 2.91 & 2.70 & $2.75^{\mathrm{AB}}$ & $2.41^{\mathrm{B}}$ & $3.26^{\mathrm{A}}$ & 2.74 & 2.87 & \multirow{2}{*}{ ns } \\
\hline & SE & 0.12 & 0.13 & 0.13 & 0.12 & 0.15 & 0.12 & 0.15 & 0.13 & 0.13 & \\
\hline \multirow{2}{*}{$\begin{array}{l}\text { MDA } \\
\mu \mathrm{mol} \mathrm{L}^{-1}\end{array}$} & LSM & 0.20 & 0.21 & 0.21 & 0.20 & $0.17^{\mathrm{B}}$ & $0.25^{\mathrm{A}}$ & $0.19^{\mathrm{B}}$ & $0.12 * *$ & $0.28 * *$ & \multirow{2}{*}{ GxR* } \\
\hline & SE & 0.02 & 0.02 & 0.02 & 0.02 & 0.02 & 0.03 & 0.02 & 0.01 & 0.01 & \\
\hline
\end{tabular}

Symbols as in the footnote to Table 2 .

\section{Discussion}

In a properly functioning organism, a balance exists between oxidative processes and defence mechanisms. The oxidative agents are products of lipid peroxidation (peroxide radicals, malondialdehyde). In turn, the antioxidative system is constituted by endogenous and exogenous substances being suppressive against radicals (RFT), including enzymes: SOD, glutathione peroxidase $\left(\mathrm{PG}_{\mathrm{X}}\right)$, and CAT, as well as many low-molecular antioxidants, e.g. ascorbic acid, bilirubin, uric acid, urea, glutathione, and tocopherol, that build the FRAP (4). The evaluation of the oxidoreductive (redox) status may refer to both the physiological and pathological state of the body or may be used to investigate effects of antioxidants administered with a diet on that status (2). The significantly lower - when compared to the control group - activities of SOD and CAT, and increased levels of FRAP and vitamin $\mathrm{C}$ in blood plasma of the lambs (especially those from E-1 group) fed the feed mixture with $1.5 \%$ addition of the PX concentrate is a positive effect. Presumably, the addition of the PX concentrate, characterised by a high antioxidative potential (23), perfectly replenishes shortages of low-molecular antioxidants, thus stimulating mechanisms of the antioxidative defence of lambs' body. Results of the research conducted by Deger et al. (8) prove that the application of antioxidants in sheep feeding may significantly suppress the mechanisms of formation of radicals and stress owing to the stimulation of antioxidative reactions. As reported by Barham et al.
(3), the enhanced activity of SOD and CAT is observed upon the generation of high quantities of hydrogen peroxide in the body, which was, however, not confirmed in the present study. A difficult to interpret exception was the increased level of MDA in the final fattening period of the lambs receiving $1.5 \%$ of the PX concentrate in the feed mixture. It is likely that, apart from a numerous groups of bioflavonoids present in alfalfa, the stimulation of the antioxidative potential of blood plasma of the lambs is additionally connected with selected proteins. A few reports are available, which point to the antioxidative properties of proteins extracted from various plants, including alfalfa leaves $(18,20,27)$. Alfalfa proteins display the capability for electrons or hydrogen donation, and thereby are able to neutralise peroxide, hydroxyl, and DPPH radicals (28). The high radical-scavenging activity of alfalfa proteins additionally enhances the antioxidative effects of active compounds being its constituents. A research by $\mathrm{Fu}$ (11) conducted on mice demonstrated that proteins of alfalfa leaves were reducing the concentration of MDA and were increasing the FRAP level. Positive effects of applying alfalfa silage were shown in dairy cows feeding, where contents of non-enzymatic antioxidants (vitamin E) were increasing in both blood plasma and milk (6). The stimulating effect on the antioxidative status was also reported upon administering a PX concentrate from alfalfa in feed mixtures for turkey toms (23) and turkey hens (7). The results of our experiments showed no effect of lambs' sex and a significant effect of their genotype on the analysed blood markers of the redox status. No effect of sex differences of healthy 
sheep on the levels of redox parameters (MDA, SOD, CAT, GPX) was demonstrated by Nazifi et al. (21). Unfortunately, the available literature provides scarce information on the effect of sex and genotype of sheep on changes in oxido-reducing parameters of their blood; hence, confrontation of the obtained results with findings of other authors is difficult. Analyses of experiments conducted on the lambs demonstrated that the activities of SOD and CAT diminished along with the growth of the animals. When investigating the activity of SOD in blood of sheep, Sgorlon et al. (26) showed an ascending tendency of this parameter with the age of animals. In turn, the authors firstly observed an increase, followed by a decrease in the level of MDA with the age of the animals, which is consistent with the results of our study.

In summary, considering the results of the stimulation of the antioxidative defence response in lambs, and the economic aspect, the application of $1.5 \%$ addition of the protein-xanthophyll (PX) concentrate from alfalfa seems to be more advisable. The sex of the lambs had no significant effect on changes in redox parameters of blood. In turn, the PLS genotype of lambs was found to determine an increase in the values of the analysed parameters (SOD, FRAP, MDA, vitamin C), in comparison to the values noted for the BCP line lambs. A descending tendency in SOD and CAT activities, as well as an ascending tendency in FRAP level were noted during the growth of the animals.

Acknowledgments: The paper is supported by the project No. 12000506 from the National Center of Research and Development.

\section{References}

1. Aziz A.B., Grossman S., Budowski I., Ascarielli I., Bondi A.: Antioxidant properties of lucerne extracts. Food Agricult 2006, 19, 605-608.

2. Bałasińska B.: Evaluation of the redox in living organisms. Medycyna Wet 2004, 60, 579-583.

3. Barham S., Truchliński J., Ognik K.: Peroxidation of lipids in rats' organs during acute pancreatitis. Medycyna Wet 2006, 62, 440-443.

4. Bartosz G.: Second face of oxygen. PWN, Warszawa, 2004.

5. Benzie I.F.F., Strain J.J.: The ferric reducing ability of plasma (FRAP) as a measure of antioxidant power the FRAP assay. Anal Biochem 1996, 239, 70-76.

6. Calderon F., Chauveau-duriot B., Pradel P., Martin B., Graulet B., Doreau M., Noziere P.: Variations in carotenoids, vitamin A and E, and color in cow's plasma and milk following a shift from hay diet to diets containing increasing levels of carotenoids and vitamin E. J Dairy Sci 2007, 90, 5651-5664.

7. Czech A., Ognik K., Grela R.E.: Efficacy of a mixture of synthetic antioxidant and protein-xanthophyll alfalfa concentrate in turkey hens feeding. Archiv für Geflügelk, 2012, 76, 105-112.

8. Deger Y., Ertekin A., Deger S., Mert H.: Lipid peroxidation and antioxidant potential of sheep liver infected naturally with distomatosis. Türki Parazitol Derg 2008, 32, 23-26.
9. Dong K.F., Gao W.W., Tong J.M., Jia H.Q., Sar N., Zang Q.: Effect of polysavone (alfalfa extract), on abdominal fat deposition and immunity in broiler chickens. Poult Sci 2007, 86, 1955-1959.

10. EFSA: Opinion on the safety of "Alfalfa protein concentrate" as food. EFSA J 2009, 997, 1-19.

11. Fu X.: Effect on plant leaf protein on lipotropy peroxidase system of rats. Chin J Vet Sci Technol 2003, 11, 1-18.

12. Gay C., Gębicki J.M.: A critical evaluation of the effect of sorbitol on the ferric-xylenol orange hydroperoxide assay. Anal Biochem 2000, 284, 217-220.

13. Gay C., Gębicki J.M.: Perchloric acid enhances sensitivity and reproducibility of the ferric-xylenol orange peroxide assay. Anal Biochem 2002, 304, 42-46.

14. Głowniak K., Widelski J., Skalicka-Woźniak K.: Alfalfa underestimated medicinal raw. Panacea 2007, 3, 20.

15. Greenwald R.A.: CRC Handbook of methods for oxygen radical research. CRC Press Boca Raton. Polish Academy of Science, Institute of Physiology and Animal Nutrition, Jabłonna, 1985.

16. Grela E.R.: Nutritional value of alfalfa and concentrate PX efficiency in animal nutrition. In: Alfalfa in human and animal nutrition. $3^{\text {rd }}$ International Conference ,Feed and Food Additives", Dzierdziówka-Lublin, 2008, pp. 77-91.

17. Jarrige R.: Ruminant nutrition. Recommended allowances and feed tables. INRA, Paris, 1989.

18. Je J.Y., Park P.J., Kim S.K.: Antioxidant activity of a peptide isolated from Alaska pollack (Theragra chalcogramma) frame protein hydrolysate. Food Res Inter 2005, 38, 45-50.

19. Khaleel A.E., Gad M.Z., El-Maraghy S.A., Hifnawy M.S., Abdel-Satter E.: Study of hypocholesterolemic and antiatherosclerotic properties of Medicago sativa 1 . cultivated in Egypt. J Food Drug Anal 2005, 13, 212218.

20. Moure A., Dominguez H., Parajo J.C.: Antioxidant properties of ultrafiltration - recovered soy protein fractions from industrial effluents and their hydrolysates. Process Biochem 2006, 41, 447-456.

21. Nazifi S., Ghafari N., Farshneshani F., Rahsepar M., Razavi S.M.: Reference values of oxidative stress parameters in adult Iranian fat-tailed sheep. Pakistan Vet J 2010, 30, 13-16.

22. Newall C.A., Anderson L.A., Phillopson J.D.: Herbal medicines. A guide for health-care professionals. The Pharmaceutical Press, London, 1996.

23. Ognik K., Czech A.: Effect of the addition of proteinxantophillic concentrate from alfalfa (Medicago sativa) on the antioxidant potential of turkey toms blood. Zesz Nauk Pol Tow Zootech 2010, 6, 77-86.

24. Omaye S.T., Tumbull J.D., Sauberlich H.E.: Selected methods for determination of ascorbic acid in animal cells, tissues and fluids. Meth Enzymol 1979, 62, 3-11.

25. Salih M., Smith D.M., Price J.F., Dawson L.E.: Modified extraction 2-thiobarbituric acid method for measuring lipid oxidation in poultry. Poult Sci 1987, 66, 14831488 .

26. Sgorlon S., Stradaioli G., Zanin D., Stefanon B.: Biochemical and molecular responses to antioxidant supplementation in sheep. Small Rum Res 2006, 64, 143-151.

27. Uchida K., Kawakishi S.: Sequence-dependent reactivity of histidine-containing peptides with copper (II)/ ascorbate. J Agric Food Chem 1992, 101, 1658-1663.

28. Xie Z., Huang J., Xu X., Jin Z.: Antioxidant activity of peptides isolated from alfalfa leaf protein hydrolysate. Food Chem 2008, 111, 370-376. 